\title{
Pengaruh Citra LAZ OPSEZI Kota Jambi terhadap Minat Muzakki untuk Menyalurkan Zakat
}

\author{
Ambok Pangiuk, Bambang Kurniawan, Marya Ulpa \\ Fakultas Ekonomi dan Bisnis Islam UIN Sulthan Thaha Saifuddin Jambi
}

\begin{abstract}
Abstrak: Tulisan ini mengkaji pengaruh citra lembaga terhadap minat pemberi zakat atau muzakki untuk menyalurkan zakatnya. Penelitian dilakukan pada Lembaga Amil Zakat (LAZ) OPSEZI Kota Jambi yang telah melakukan berbagai program. Metode penelitian adalah campuran kuantitatif dan kualitatif, yaitu melalui teknik pengumpulan data kuisioner, wawancara, observasi, dan penghimpunan dokumen yang berkaitan dengan penelitian ini. Populasi dalam penelitian adalah muzakki yang membayar zakatnya pada amil zakat OPSEZI Kota Jambi pada tahun 2015-2017, sedangkan sampel penelitian berjumlah 96 orang muzakki yang diperoleh melalui teknik sampel acak atau random sampling. Uji validitas, uji realibilitas, uji normalitas, uji multikolinieritas, uji heteroskedastisitas, uji t, uji regresi linier sederhana dan koefisien determinasi juga telah dilakukan. Dari hasil uji T yang dilakukan diketahui besarnya nilai $t_{\text {hitung }}$ variabel citra lembaga $(0,000)<$ dari 0,05 hal ini berarti ada pengaruh signifikan terhadap variabel minat. Nilai koefisien determinasi adalah sebesar 0,509 atau sama dengan 50,9\% . Hal ini menunjukkan bahwa variabel citra lembaga LAZ OPSEZI terhadap minat muzakki untuk menyalurkan zakat di LAZ OPSEZI Kota Jambi berpengaruh sebesar 50,9\% sedangkan $49,1 \%$ dipengaruhi oleh faktor-faktor lain yang tidak dibahas dalam penelitian ini. Dari hasil regresi linier sederhana yang dilakukan diketahui bahwa nilai $t_{\text {hitung variabel citra }}$ lembaga mempunyai pengaruh sebesar (9.874) hal ini berarti bahwa variabel citra lembaga berpengaruh terhadap minat muzakki untuk menyalurkan zakat di LAZ OPSEZI Kota Jambi.
\end{abstract}

Kata-kata kunci: zakat; OPSEZI; Jambi.

\section{Pendahuluan}

Seiring perkembangan zaman, manusia telah menyadari bahwa segala hal yang berhubungan dengan agama itu sangat penting, mulai dari pendidikan, akhlak, etika berbusana sampai pada kesadaran untuk menunaikan zakat. Zakat menurut bahasa berarti tumbuh, berkembang, subur, bertambah, menyucikan, dan membersihkan. Adapun secara terminologi, zakat menurut istilah fikih berarti sejumlah harta tertentu yang diwajibkan Allah diserahkan kepada orang-orang yang berhak, disamping berarti mengeluarkan jumlah tertentu itu sendiri. ${ }^{1}$ Sedangkan dalam Undang-undang pengelolaan zakat nomor 23 tahun 2011 yang dimaksud dengan zakat adalah harta yang wajib dikeluarkan oleh seorang muslim atau badan usaha untuk diberikan kepada yang berhak menerimanya sesuai dengan syariat Islam.

${ }^{1}$ Mardani, Aspek Hukum Lembaga Keuangan Syariah di Indonesia, Jakarta: Kharisma Putra Utama, 2015, hlm.239. 
Dalam konteks kontemporer, beberapa instrumen mengalami metamorfosa dan penyesuaian-penyesuaian, kecuali instrumen yang secara eksplisit telah ditetapkan oleh agama seperti zakat dan waqaf. Berkembangnya dari zakat dan waqaf ini ada pada aspek harta objek zakat dan waqaf. Zakat penghasilan/profesi, zakat perusahaan dan waqaf uang adalah contoh pengembangan instrumen pembiayaaan pembangunan yang sangat relevan dengan kondisi hari ini. Persoalan zakat menjadi signifikan bukan saja karena dimensi mahdah (Ibadah semata) dan soal yang dimilikinya, melainkan juga terjadinya perluasan dan perkembangan pada sektor-sektor yang dikenai wajib zakat. Zakat juga menjadi salah satu sumber pendanaan pembangunan dengan dana bersumber dari muzakki dan disalurkan pada mustahik. ${ }^{2}$

Pada masa awal Islam sektor jasa bukan hal dominan, berbeda dengan globalisasi sekarang ini, sektor jasa merupakan lahan strategis dan memiliki nilai ekonomis tinggi. Sehingga tidak ragu lagi para ulama muta'akhirin mengidentifikasikan hasil pendapatan dari jual jasa ini diwajibkan terkena zakat. Diantara hal-hal yang sangat penting untuk mendapatkan perhatian kaum muslimin saat ini adalah penghasilan atau pendapatan yang diusahakan melalui keahliannya, baik keahlian yang dilakukan secara mandiri maupun secara bersama-sama, penghasilan atau pendapatan yang dihasilkan dari semua profesi itu wajib dikeluarkan zakatnya. Jika dibedah lebih dalam, potensi zakat nasional ini terdiri dari 3 komponen utama, yaitu zakat penghasilan rumah tangga, zakat perusahaan dan zakat tabungan dan investasi keuangan syariah. ${ }^{3}$

Setiap perusahaan maupun lembaga harus mempunyai nama di tengah masyarakat, dan nama itu sendiri dapat berpredikat baik, sedang maupun buruk. Untuk hal ini, perusahaan lebih sering bersifat proaktif, tidak dengan cara menunggu dan membiarkan proses pembentukan citra tersebut berjalan tanpa kendali. Oleh karena itu, manajemen berusaha merumuskan harapannya tentang citra publik terhadap perusahaan di dalam misi perusahaan. ${ }^{4}$ Citra buruk dapat menimbulkan hal yang negatif bagi perusahaan/lembaga dan juga dapat melemahkan kemampuannya untuk bersaing. Citra yang baik dari suatu organisasi merupakan aset yang sangat penting karena citra mempunyai suatu dampak atas persepsi masyarakat dan operasi organisasi dalam segala hal. ${ }^{5}$

Lembaga zakat Optimalisasi Sedekah Zakat dan Infaq (OPSEZI) adalah lembaga amil zakat yang hadir untuk membangun kesadaran masyarakat khususnya di wilayah Jambi. OPSEZI didirikan pada tahun 2005 dengan misi amanah, profesional dan transparan dan bermanfaat bagi masyarakat. Adapun program-program penyaluran zakat yang dikeluarkan oleh OPSEZI yaitu OPSEZI educare, Beasiswa, OPSEZI heal care, layanan kesehatan gratis, khitanan massal, klinik dhuafa, masyarakat mandiri, OPSEZI peduli, aqiqah barokah, pelangi

\footnotetext{
2 Irfan Syauqi Beik - Laily Dwi Arsyianti, Ekonomi Pembangunan Syariah, Jakarta: Raja Grafindo Persada, 2018, hlm.180-181.

${ }^{3}$ Irfan Syauqi Beik - Laily Dwi Arsyianti, Ekonomi Pembangunan, hlm.182.

${ }^{4}$ Muhammad, Suwarsono, Manajemen Strategi Konsep dan Alat Analisis, Yogyakarta: Unit Penerbit dan Percetakan Sekolah Tinggi Ilmu Manajemen YKPN, 2013, hlm. 43.

5 Firsan Nova, CRISIS Public Relations: Strategi PR Menghadapi Krisis, Mengelola Isu, Membangun Citra, dan Reputasi Perusahaan, hlm. 302-303.
} 
ramadhan, qurban bersama OPSEZI, celengan qurban dan berbagai program lainnya. ${ }^{6}$

Keberhasilan lembaga zakat bukan dilihat dari seberapa banyak jumlah dana yang terkumpul, tetapi juga pada dampak dari pendistribusian dan pendayagunaan zakat tersebut yaitu dapat mewujudkan keadilan dan kesejahteraan sosial bagi masyarakat. Muzakki mana yang tidak bahagia bila melihat zakat yang disalurkannya melalui badan amil zakat kemudian di distribusikan dengan baik dan tepat sesuai dengan kondisi dan kebutuhan masyarakat. Pada akhir tahun 2016 yang lalu OPSEZI bekerja sama dengan pemerintahan kota Jambi sukses mengadakan sunatan massal untuk anak-anak yatim dan anak-anak kurang mampu yang pesertanya kurang lebih mencapai 700 orang. Selain itu pada saat idul adha OPSEZI juga sukses menyalurkan daging qurban ke daerah-daerah yang minim masyarakatnya berqurban. Di bidang beasiswa OPSEZI juga sukses menyalurkan beasiswa dengan baik kepada pelajarpelajar jambi yang sangat membutuhkan bantuan. ${ }^{7}$

Membangun citra organisasi dan lembaga amanah profesional itu sangat penting dilakukan, mengingat saat ini telah terjadi krisis kepercayaan antar sesama komponen masyarakat. Pembangunan citra ini merupakan hal yang sangat penting dan berpengaruh mengingat citra yang baik dan kuat akan membuat daya tarik tersendiri bagi muzakki untuk bersedia menyalurkan dana zakatnya. Sebaliknya jika citra suatu lembaga buruk di tengah masyarakat akan mengakibatkan rendahnya minat para muzakki untuk menyalurkan zakat di lembaga zakat tersebut.

${ }^{6}$ Brosur Lembaga Amil Zakat OPSEZI Kota Jambi

${ }^{7}$ Wawancara bersama Ibu Yanita, selaku bagian Humas di Lembaga Amil Zakat OPSEZI kota Jambi, tanggal 20 Maret 2018. 
Tabel. 1.1 Data Penerimaan zakat Lembaga Amil zakat OPSEZI Kota Jambi Tahun $2015-20178$

\begin{tabular}{|c|c|c|c|c|}
\hline No & & Tahun & Jumlah Muzakki & $\begin{array}{c}\text { Jumlah zakat yang } \\
\text { diterima }\end{array}$ \\
\hline \multirow[t]{5}{*}{1} & \multirow[t]{5}{*}{2015} & 01-Jan-15 & & Rp. 169.257.833,20 \\
\hline & & Triwulan I & 98 & Rp. $156.418 .315,40$ \\
\hline & & Triwulan II & 145 & Rp. 213.507.894.47 \\
\hline & & Triwulan III & 286 & Rp. $688.210 .217,09$ \\
\hline & & Triwulan IV & 137 & Rp. $196.768 .355,15$ \\
\hline \multirow[t]{4}{*}{2} & \multirow[t]{4}{*}{2016} & Triwulan I & 75 & Rp. $210.968 .162,11$ \\
\hline & & Triwulan II & 208 & Rp. $422.917 .644,58$ \\
\hline & & Triwulan III & 265 & Rp.672.161.773,82 \\
\hline & & Triwulan IV & 197 & Rp. $391.469 .934,54$ \\
\hline \multirow[t]{5}{*}{3} & \multirow[t]{5}{*}{2017} & Triwulan I & 87 & Rp. $322.642 .481,43$ \\
\hline & & Triwulan II & 215 & Rp. $1.063 .208 .102,65$ \\
\hline & & Triwulan III & 397 & Rp. 590.272.707,80 \\
\hline & & Triwulan IV & 175 & Rp. 469.892.490,11 \\
\hline & & 31-Des-17 & & Rp. 131.099.798,59 \\
\hline \multicolumn{3}{|c|}{ Total } & 2.285 & Rp. 5.398.438.079,15 \\
\hline
\end{tabular}

Dari data di atas, dapat diamati bahwa dari tahun 2015 sampai 2016 Triwulan I ke Triwulan III mengalami kenaikan, namun dari Triwulan III ke Triwulan IV mengalami penurunan. Pada tahun 2017, penerimaan zakat mengalami fluktuatif yakni dari Triwulan I ke Triwulan II mengalami kenaikan, namun pada Triwulan ke III dan ke IV mengalami penurunan

${ }^{8}$ Data diperoleh dari Lembaga Amil Zakat OPSEZI Kota Jambi. 
Tabel 1.2 Data Penyaluran zakat oleh Lembaga Amil Zakat OPSEZI Kota Jambi Tahun 2015-20179

\begin{tabular}{|c|c|c|c|c|c|}
\hline No & \multicolumn{2}{|r|}{ Tahun } & $\begin{array}{c}\text { Jumlah zakat yang } \\
\text { diterima }\end{array}$ & $\begin{array}{c}\text { Jumlah zakat yang } \\
\text { disalurkan }\end{array}$ & $\begin{array}{l}\text { Jumlah } \\
\text { Mustahiq }\end{array}$ \\
\hline \multirow[t]{5}{*}{1} & \multirow[t]{5}{*}{2015} & 1-Jan-2015 & Rp. $169.257 .833,20$ & & \\
\hline & & Triwulan I & Rp. 156.418.315,40 & Rp. $129.090 .439,66$ & 521 \\
\hline & & Triwulan II & Rp. 213.507.894.47 & Rp. 208. 396.201,20 & 925 \\
\hline & & Triwulan III & Rp. 688.210.217,09 & Rp. 659.774.991,71 & 1.706 \\
\hline & & Triwulan IV & Rp. 196.768.355,15 & Rp. 274.019.998,76 & 684 \\
\hline \multirow[t]{4}{*}{2} & \multirow[t]{4}{*}{2016} & Triwulan I & Rp. 210.968.162,11 & Rp. 207. 772.753,14 & 432 \\
\hline & & Triwulan II & Rp. 422.917.644,58 & Rp. 333. 461.823,98 & 1.845 \\
\hline & & Triwulan III & Rp.672.161.773,82 & Rp. 776. 801.017,14 & 2.502 \\
\hline & & Triwulan IV & Rp. 391.469.934,54 & Rp. 427.957.754,72 & 1.025 \\
\hline \multirow[t]{5}{*}{3} & \multirow[t]{5}{*}{2017} & Triwulan I & Rp. 322.642.481,43 & Rp. 312. 482.492,65 & 498 \\
\hline & & Triwulan II & Rp. 1.063.208.102,65 & Rp. 1. 019.431.006,93 & 1.278 \\
\hline & & Triwulan III & Rp. 590.272.707,80 & Rp. 562. $261.040,45$ & 3.235 \\
\hline & & Triwulan IV & Rp. 469.892.490,11 & Rp.525.146.643,42 & 973 \\
\hline & & 31-Des-17 & Rp. 131.099.798,59 & & \\
\hline \multicolumn{3}{|c|}{ Total } & Rp. 5.398.438.079,15 & Rp. 5. 436. 596.163,76 & 15.624 \\
\hline
\end{tabular}

Dilihat dari data penyaluran zakatnya, ada sedikit perbedaan antara jumlah yang diterima dengan jumlah yang disalurkan. Hal ini dikarenakan dari pengakumulasian dana tahun sebelumnya.

Namun hal yang tidak sejalan dengan program-program yang telah dilakukan oleh lembaga amil zakat Opsesi yaitu masih kurangnya minat masyarakat untuk menyalurkan zakatnya kepada lembaga ini. Hal ini dijelaskan oleh salah satu karyawati bagian Humas, (Yanita) bahwa masih kurangnya minat dari masyarakat kota Jambi untuk membayar zakat. Sedangkan dari Lembaga sendiri telah melakukan berbagai program atau bisa dikatakan promosi seperti, 1)Opsesi Healthcare (layanan kesehatan gratis, khitanan massal gratis yg dilakukan setiap libur semester sekolah, klinik dhuafa), 2) Opsesi Educare (beasiswa yatim \& Dhuafa, Rumah baca yang berlokasi di mayang, dan Opsesi goes to school), 3)Aqiqah barokah 4)Opsesi Ecosocare (Opsesi peduli, Sembako: penyaluran sedekah sembako dan nasi bungkus untuk kaum Lansia dan dhuafa yg diberikan setiap hari jum'at ), selain program dalam bentuk konsumtif,OPSEZI juga memiliki program dalam bentuk produktif yakni memberikan bantuan berupa program masyarakat mandiri yang mana OPSEZI memberikan bantuan modal untuk dikelolah oleh mustahiq yang ingin membuka usaha. ${ }^{10}$

9 Data diperoleh dari Lembaga Amil Zakat OPSEZI Kota Jambi.

10 Wawancara bersama ibu Yanita, selaku bagian Humas di Lembaga Amil Zakat OPSEZI kota Jambi, tanggal 20 maret 2018. 
Hal ini mungkin disebabkan karena masih kurangnya pemahaman masyarakat yang belum banyak mengetahui keberadaan lembaga zakat ini, sehingga masyarakat banyak memilih untuk menyalurkan zakat ke Badan amil zakat Nasional (BASNAZ). Hal ini dilihat dari data yang diperoleh dari Baznas Provinsi Jambi pada tahun 2014, bahwa zakat yang dapat dikumpulkan oleh BAZNAS ini sebesar Rp.2.792.019.458,81 dalam setahun. Sedangkan di lembaga amil zakat OPSEZI Kota Jambi zakat yang dikumpulkan rata-rata hanya 1.618.272.389 dalam setahun. Ini menunjukkan bahwa masyarakat lebih dominan menyalurkan zakatnya di BASNAZ Provinsi Jambi.

Dari sisi pengumpulan zakat, permasalahan yang paling sering terjadi dan paling besar adalah kesenjangan yang sangat besar antara potensi zakat dengan realisasi pengumpulan zakat serta pendistribusian zakat.11 Salah satu faktor yang mungkin menjadi penyebab adalah citra perusahaan atau lembaga amil zakat yang masih belum baik dari pandangan masyarakat sekitarnya.

Dari berbagai kegiatan dan program yang telah dijalankan, tetap saja masih kurangnya minat dari masyarakat kota Jambi dan sekitarnya untuk menyalurkan zakat.

Maka dengan latar belakang dan agar tidak menyimpang dari pembahasan maka penulis merumuskan masalah apakah citra lembaga amil zakat OPSEZI secara parsial berpengaruh terhadap minat muzakki untuk menyalurkan zakatnya pada lembaga zakat OPSEZI Kota Jambi.

\section{Citra Lembaga dan Muzakki}

Citra dalam penelitian ini diartikan sebagai gambaran yang dimiliki oleh orang banyak mengenai pribadi, organisasi, maupun produk yang ada pada sebuah lembaga atau perusahaan. ${ }^{12}$ Citra diartikan sebagai persepsi masyarakat terhadap perusahaan atau produknya. Citra lembaga adalah kesan atau persepsi seorang terhadap lembaga atau produknya yang dipengaruhi oleh faktor diluar kontrol lembaga. 13

Informasi yang lengkap mengenai citra lembaga meliputi 4 elemen sebagai berikut: ${ }^{14}$

1. Personality. Keseluruhan karakteristik perusahaan yang dipahami publik sasaran seperti perusahaan yang dapat dipercaya, perusahaan mempunyai tanggung jawab sosial.

2. Reputation, hal yang dilakukan perusahaan dan diyakini publik sasaran berdasarkan pengalaman sendiri maupun pihak lain, seperti kinerja keamanan transaksi sebuah bank.

\footnotetext{
${ }^{11}$ Hanwar Ahmad Sidiq, "Pengetahuan Zakat, Tingkat Pendapat, Religiusitas dan Kepercayaan kepada Organisasi Pengelolaan Zakat Terhadap Minat Membayar Zakat pada Lembaga Amil Zakat" Skripsi (Surakarta: Universitas Muhammadiyah,2015), hlm 4.

12 Kamus Umum Bahasa Indonesia Pusat Bahasa Edisi Keempat,Jakarta: PT Gramedia Pustaka Utama, 2008

${ }^{13}$ Firsan Nova, CRISIS Publik Relations: Strategi PR Menghadapi Krisis, Mengelola Isu, Membangun Citra, dan Reputasi Perusahaan, (Jakarta: Rajawali Press, 2011), hlm. 298-299.

14 Imam Mulyana Dwi Suwandi, Citra Perusahaan Seri Manajemen Pemasaran, www.eiman.uni.cc diakses pada 11 Oktober 2018 pukul 12.10 WIB.
} 
3. Value, nilai-nilai yang dimiliki perusahaan dengan kata lain budaya perusahaan seperti sikap manajemen yang peduli terhadap pelanggan, karyawan yang cepat tanggap terhadap permintaan maupun keluhan pelanggan.

4. Corporate Identity, adalah komponen-komponen yang mempermudah mengenai publik sasaran terhadap perusahaan seperti logo, warna, dan slogan.

Citra perusahaan atau lembaga adalah citra dari organisasi secara keseluruhan bukan hanya produk dan pelayanannya. Citra merupakan aset yang terpenting dari suatu perusahaan atau organisasi. Citra yang baik akan dapat mendukung aktivitas suatu lembaga. Citra yang baik dari suatu lembaga juga akan mempunyai dampak yang menguntungkan karena citra mempunyai suatu dampak pada persepsi publik dari komunikasi dan operasi lembaga dalam berbagai hal, sedangkan citra yang jelek bisa merugikan suatu lembaga. ${ }^{15}$

Citra seseorang dapat diketahui dari sikap terhadap objek tertentu. Sikap mengandung tiga unsur yaitu kognitif (pengetahuan), afektif (emosi, perasaan), dan konaktif (tindakan). Dengan demikian pembentukan citra lembaga oleh individual berkaitan dengan faktor emosional yang ada dalam diri seseorang.

Minat sendiri adalah kecenderungan hati terhadap sesuatu. ${ }^{16}$ Minat adalah rasa lebih suka dan rasa ketertarikan pada suatu hal atau aktivitas, tanpa ada yang menyuruh. Minat pada dasarnya adalah penerimaan suatu hubungan antara diri sendiri dengana sesuatu di luar diri. Semakin kuat atau dekat hubungan tersebut, semakin besar minatnya. ${ }^{17}$

Secara sederhana, minat adalah kecendrungan untuk memberikan perhatian dan bertindak terhadap orang, aktivitas, atau situasi yang menjadi objek dari minat tersebut disertai perasaan senang. ${ }^{18}$ Sedangkan menurut istilah ialah suatu perangkat mental yang terdiri dari suatu campuran dari perasaan, harapan, pendirian, prasangka atau kecendrungan lain yang mengarahkan individu kepada suatu pilihan tertentu. ${ }^{19}$

Faktor - faktor yang mendasari minat yaitu ${ }^{20}$ :

1. Faktor dorongan dari dalam

Faktor dari dalam berupa kebutuhan yang berhubungan dengan jasmani dan kejiwaan.

2. Faktor dorongan yang bersifat sosial

Timbulnya minat dari diri seseorang juga dapat didorong oleh adanya motivasi sosial yaitu mendapatkan pengakuan dan penghargaan dari lingkungan masyarakat dimana seseorang berada.

3. Faktor yang bersifat emosional

\footnotetext{
15Frank Jefkins dan Daniel Yadien, Public Relation, terj. Haris Munandar, (Jakarta: Erlangga,2003),hlm. 22.

${ }^{16}$ Kamus Umum Bahasa Indonesia Pusat Bahasa Edisi Keempat,(Jakarta: PT Gramedia Pustaka Utama, 2008), hlm. 916.

${ }^{17}$ Djaali. Psikologi Pendidikan. .., hlm.12.

${ }^{18}$ Abdul Rahman Shaleh dan Muhbib Abdul Wahab, Psikologi Suatu Pengantar Dalam Perspektif Islam,(Jakarta: Kencana, 2004), hlm. 262-263.

${ }^{19}$ Andi Mappiare, Psikologi Remaja, ...,hlm.62.

${ }^{20}$ Ibid., hlm.264
} 
Faktor emosional memperlihatkan ukuran intensitas seseorang dalam menanam perhatian terhadap suatu kegiatan atau objek tertentu.

Aspek- aspek yang terdapat dalam minat yaitu: ${ }^{21}$

1. Ketertarikan (interest) yang menunjukkan adanya pemusatan perhatian dan perasaan senang.

2. Keinginan (Desire) ditunjukkan dengan adanya dorongan untuk ingin memiliki.

3. Keyakinan (conviction) ditunjukkan dengan adanya perasaan percaya diri individu terhadap kualitas, daya guna, dan keuntungan dari produk yang akan dibeli.

Minat merupakan kecenderungan untuk menentukan pilihan aktivitas. Pengaruh kondisi individual dapat merubah minat seseorang sehingga dikatakan minat sifatnya tidak stabil.22 Penyebab minat salah satunya berasal dari faktor emosional yaitu minat yang mempunyai hubungan yang erat dengan emosi. Bila seseorang mendapatkan kesuksesan pada aktivitas akan menimbulkan perasaan senang, dan hal tersebut akan memperkuat minat terhadap aktivitas tersebut, sebaliknya suatu kegagalan akan menghilangkan minat terhadap hal tersebut. Dalam hal ini jika seseorang melihat citra yang baik maka akan diharapkan dapat menimbulkan minat muzakki untuk menyalurkan zakatnya. ${ }^{23}$

Menurut kamus Umum bahasa Indonesia, muzakki didefenisikan sebagai orang yang wajib membayar zakat, infaq,dan sedekah. ${ }^{24}$ Muzakki adalah orang yang dikenai kewajiban membayar zakat atas kepemilikan harta yang telah mencapai nisab dan haul. ${ }^{25}$ Minat Muzakki dalam penelitian ini adalah kecendrungan hati muzakki untuk menyalurkan zakatnya pada Laz Amil Zakat OPSEZI Kota Jambi.

Zakat secara bahasa zakat berarti an-numu wa az -ziyadah (tumbuh dan bertambah). ${ }^{26}$ Sedangkan zakat secara syar'i adalah bagian tertentu dari harta tertentu yang dibayarkan kepada orang tertentu yang berhak menerimanya sebagai ibadah dan ketaatan kepada Allah. ${ }^{27}$ Dalam Al-Qur'an juga menjelaskan tentang zakat, yakni QS. At-Taubah ayat $103,{ }^{28}$

21 Ahmad Rendi. Pengaruh kualitas pelayanan dan citra lembaga terhadap minat masyarakat berinfaq di LAZNAS DPU DT Cabang Palembang. Skripsi (Palembang: UIN Raden Fatah, 2017), hlm.32

22 M.Abdul Rouf,Analisis Faktor-faktor Yang Mempengaruhi Minat Masyarakat Membayar Zakat di Rumah Zakat Cabang Semarang, Skripsi Tidak Diterbitkan, (Semarang: Institut Agama Islam Negeri Walisongo, 2011)

${ }^{23}$ Abdul Rahman Shaleh dan Muhbib Abdul Wahab, Psikologi Suatu Pengantar, hlm.264.

24 J.S Badudu dan Sutan Muhammad Zain, Kamus Umum Bahasa Indonesia,(Jakarta: Pustaka Sinar Harapa), hlm.932.

${ }^{25}$ M. Syafi'ie El-Bantanie, Zakat Infak dan Sedekah, (Bandung: PT. Salamadani Pustaka Semesta, 2009), hlm.9.

26Ibid., hlm.247

${ }^{27}$ Husayn Syahatah. Akuntansi Zakat Panduan Praktis Penghitung Zakat Kontemporer. (Jakarta: Pustaka Progressif, 2004), hlm.4 Arkmleemaa

28 Dapartemen Agama RI. Al-Quran dan Terjemahnya. Bandung Sygma Examedia 
Ambillah zakat dari sebagian harta mereka, dengan zakat itu kamu membersihkan dan mensucikan mereka dan mendoalah untuk mereka. Sesungguhnya doa kamu itu (menjadi) ketenteraman jiwa bagi mereka. dan Allah Maha mendengar lagi Maha mengetahui.

Makna zakat dari istilah fikih berarti sejumlah harta tertentu yang diwajibkan Allah untuk diserahkan kepada orang-orang yang berhak. ${ }^{29}$ Sesuai dengan pengertian zakat yang dikemukakan di atas zakat hendaknya adalah harta milik sendiri, zakat merupakan pemilikan harta tertentu untuk orang yang berhak menerimanya dengan syarat-syarat tertentu, maka yang diberikan kepada para mustahik zakat harus bersifat kpemilikan. Artinya, zakat yang diberikan tersebut menjadi milik dan dapat dimiliki secara penuh oleh mustahik yang bersangkutan. Oleh karena itu, bila harta tersebut diberikan dalam bentuk pembolehan pemanfaatannya saja ataupun bersifat pinjaman yang harus dikembalikan tidak dipandang zakat secara hukum dan zakatnya tidah sah. ${ }^{30}$

\section{Dasar Hukum Zakat}

Dasar hukum kewajiban zakat terdapat dalam beberapa firman Allah SWT dan beberapa hadist Nabi Muhammad SAW. Adapun dalil-dalil dari Al-Qur'an sebagai Berikut: ${ }^{31}$

1. Firman Allah SWT dalam QS. Al - Baqarah : 43

dan dirikanlah shalat, tunaikanlah zakat dan ruku'lah beserta orang-orang yang ruku'.

2. Firman Allah SWT dalam QS. Al-Hajj (22): 41

(yaitu)orang-orang yang jika kami teguhkan kedudukannya mereka di muka bumi, niscaya mereka mendirikan shalat, menunaikan zakat, menyuruh berbuat yang makruf dan mencegah dari perbuatan yang mungkar dan kepada Allah-lah kembali segala urusan. ${ }^{32}$

Adapun dalil yang bersumber dari hadist, sebagai berikut: ${ }^{33}$

1. Rasulullah saw, bersabdah,:

Ia mengatakan bahwa: "harta tidak berkurang karena shadaqah (zakat) dan shadaqah (zakat) tidak diterima dari pengkhianatan".(HR. Muslim)

2. Rasulullah saw, bersabdah,:

"Islam dibangun atas lima hal: persaksian bahwa tiada tuhan selain Allah dan bahwa Muhammad Rasulullah, mendirikan shalat, membayar zakat,

\footnotetext{
${ }^{29}$ Heri Sudarso. Bank dan Lembaga Keuangan Syari'ah Deskripsi dan Ilustrasi.(Yogyakarta: EKONISIA, 2004), hlm.233

${ }^{30}$ Rozalinda. Ekonomi Islam Teori dan Aplikasinya pada Aktivitas Ekonomi. (Jakarta: Rajawali Pers, 2014), 250-251

${ }^{31}$ Husayn Syahatah. Akuntansi Zakat Panduan Praktis Penghitung Zakat Kontemporer. (Jakarta: Pustaka Progressif, 2004), hlm.4 Arkmleemaa

32 Dapartemen Agama RI. Al-Quran dan Terjemahnya. Bandung Sygma Examedia

${ }^{33}$ Husayn Syahatah. Akuntansi Zakat Panduan Praktis Penghitung Zakat Kontemporer. (Jakarta: Pustaka Progressif, 2004),hlm 6-7
} 
puasa ramadhan, dan haji bagi yang mampu menempuh jalannya. (HR. AlBukhari dan Muslim)

3. Sabda Rasulullah saw kepada Mu'az bin Jabal ketika beliau mengutusnya ke Yaman,

"Maka beritahu mereka bahwa Allah Swt. telah mewajibkan atas mereka zakat yang diambil dari orang-orang kaya mereka dan dikembalikan kepada para fakir mereka." (HR. Bukhari dan Muslim)

Fungsi Zakat

Ada dua fungsi utama zakat: ${ }^{34}$

1. Zakat sebagai asuransi sosial dalam masyarakat Muslim. Nasib manusia tidak konstan pada satu kondisi saja. Adakalanya orang yang wajib membayar zakat pada masa tertentu karena memiliki kekayaan yang banyak, pada masa berikutnya, ia malah termasuk orang yang berhak menerima zakat karena musibah yang membuatnya miskin.

2. Zakat juga berfungsi sebagai jaminan sosial, karena memang ada orang-orang yang selama hidupnya belum memiliki kesempatan mendapatkan rezeki melimpah, karena itu orang-orang islam lain berkewajiban membantu mencukupi kebutuhan hidupnya.

Amil zakat adalah orang yang bertugas mengumpulkan dan membagikan zakat. Lembaga zakat biasanya terbentuk dari organisasi politik, takmir majlis, pesantren, media massa, bank dan lembaga keuangan dan lembaga kemasyarakatan.

Timbulnya lembaga-lembaga zakat merupakan cerminan timbulnya, kesadaran akan perlunya lembaga yang mampu mengelolah zakat-zakat masyarakat. Selian itu, hal ini merupakan hasil yang telah dilakukan lembaga zakat tersebut dalam membangun kesejahteraan masyarakat. Dari uraian diatas terlihat jelas gambaran bahwa zakat dapat berperan sangat penting dalam stabilitas bidang ekonomi di tengah-tengah masyarakat.

Tugas pokok amil zakat adalah:

1. Memberikan garis-garis kebijakan umum badan Amil zakat.

2. Mengesahkan rencana kerja dari badan pelaksana dan komisi pengawas.

3. Mengeluarkan fatwa syariah baik diminta maupun tidak berkaitan dengan hukum zakat yang wajib diikuti oleh pengurus badan Amil zakat.

4. Memberikan pertimbangan, saran dan rekomendasi kepada badan pelaksana dan komisi pengawas baik diminta maupun tidak.

5. Memberikan persetujuan atas laporan tahunan hasil kerja badan pelaksana dan komisi pengawas. ${ }^{35}$

\footnotetext{
${ }^{34}$ Akhmad Mujahidin, Ekonomi Islam Sejarah, Konsep, Instrumen, Negara dan Pasar.(Jakarta: PT RajaGrafindo Persada, 2013), hlm. 72-73 . Lihat juga Refky Fielnanda,. "Zakat Saham Dalam Sistem Ekonomi Islam (Kajian Atas Pemikiran Yusuf Qardhawi)." Al-Tijary 3.1 (2018): 57-67.

35 Heri Sudarso. Bank dan Lembaga Keuangan Syari'ah Deskripsi dan Ilustrasi.(Yogyakarta: EKONISIA, 2004), hlm.241-243
} 


\section{Penutup}

Berdasarkan penelitian yang dilakukan, maka diperoleh kesimpulan bahwa Penelitian ini menggunakan persamaan regresi linier sederhana, penelitian ini menunjukkan adanya pengaruh variabel citra lembaga $(\mathrm{X})$ terhadap minat muzakki (Y) di lembaga amil zakat OPSEZI Kota Jambi dengan persamaan $\mathrm{y}=1,263+$ $0,914(\mathrm{X})+$ e yang berarti bahwa pengaruh citra lembaga amil zakat OPSEZI Kota Jambi bertanda positif terhadap minat muzakki untuk menyalurkan zakat di LAZ OPSEZI Kota Jambi dan dari hasil uji t diterima bahwa pengaruh citra lembaga Laz OPSEZI berpengaruh signifikan terhadap minat muzakki untuk menyalurkan zakat. Nilai koefisien determinasi adalah sebesar 0,509 atau sama dengan 50,9\% . Hal ini menunjukkan bahwa variabel citra lembaga Laz OPSEZI terhadap minat muzakki untuk menyalurkan zakat di Laz OPSEZI Kota Jambi berpengaruh sebesar 50,9\% sedangkan $49,1 \%$ dipengaruhi oleh faktor-faktor lain yang tidak dibahas dalam penelitian ini. 


\section{BIBLIOGRAFI}

Al-Qur'an dan Terjemahannya, (Surabaya: Penerbit Fajar Mulya, 2009)

Abdul Rahman Shaleh dan Muhbib Abdul Wahab, Psikologi Suatu Pengantar dalam Perspektif Islam,(Jakarta: Kencana, 2004),

Ahmad Rendi, Pengaruh Kualitas Pelayanan dan Citra Lembaga Terhadap Minat Masyarakat Berinfaq di LAZNAS DPU DT Cabang Palembang, Palembang: Skripsi UIN Raden Fatah.2017

Akhmad Mujahidin, Ekonomi Islam Sejarah, Konsep, Instrumen, Negara dan Pasar, (Jakarta: RajaGrafindo Persada. 2013)

Amos Neolaka, Metode Penelitian Statistik, (Bandung: Remaja Rosdakarya.2014)

Ari Kristin P, Penerapan Akuntansi Zakat pada Lembaga Amil Zakat (Studi pada LAZ DPU DT Cabang Semarang).2011

Azy Athoillah Yazid, Faktor-faktor yang mempengaruhi minat muzakki dalam menunaikan zakat, Economi Jurnal Ekonomi dan Hukum Islam, Vol.,8, No.2, STAI Darul Ulum Banyuwangi.2017

Burhan Bungin, Metodologi Penelitian Kuantitatif komunikasi, Ekonomi dan Kebijakan Publik Serta Ilmu-ilmu Sosial Lainnya", 2014, Jakarta: Kencana Prenadamedia Group

Duwi Priyatno, SPSS 22 Pengolah Data Terpraktis, (Yogyakarta: Andi Offset, 2014)

Fielnanda, Refky. Zakat Saham dalam Sistem Ekonomi Islam (Kajian Atas Pemikiran Yusuf Qardhawi). Al-Tijary 3.1 (2018): 57-67.

Firsan Nova, CRISIS Publik Relations: Strategi PR Menghadapi Krisis, Mengelola Isu, Membangun Citra, dan Reputasi Perusahaan, (Jakarta: Rajawali Press,2011)

Fitriani Aulia Insani, Pengaruh Citra Lembaga Terhadap Minat Muzakki untuk Menyalurkan Zakat Profesi pada Badan Amil Zakat Nasional (BAZNAS) Kota Yogyakarta, (Yogyakarta: Skripsi UIN Sunan Kalijaga. 2017)

Hanifa Nur'aini dan M. Rasyid Ridla, 2015, Pengaruh kualitas pelayanan, citra lembaga dan religiusitas terhadap minat Muzakki untuk menyalurkan Zakat Propesi, (Yogyakarta: UIN Sunan Kalijaga. 2015)

Hanwar Ahmad Sidiq, Pengetahuan Zakat, Tingkat Pendapat, Religiusitas dan Kepercayaan kepada Organisasi Pengelolaan Zakat Terhadap Minat Membayar Zakat pada Lembaga Amil Zakat, (Surakarta: Skripsi Universitas Muhammadiyah. 2015)

Heri Sudarso, Bank dan Lembaga Keuangan Syari'ah Deskripsi dan Ilustrasi, (Yogyakarta: EKONISIA, 2004)

Husayn Syahatah, Akuntansi Zakat Panduan Praktis Penghitung Zakat Kontemporer, (Jakarta: Pustaka Progressif, 2004) 
Husein Umar, Metode Penelitian untuk Skripsi dan Tesis Bisnis, (Jakarta: Rajawali Pers, 2014)

Imam Mulyana Dwi Suwandi, Citra Perusahaan Seri Manajemen Pemasaran, www.eiman.uni.cc diakses pada 11 Oktober 2018 pukul 12.10 WIB.

Irfan Syauqi Beik - Laily Dwi Arsyianti. Ekonomi Pembangunan Syariah, (Jakarta: Raja Grafindo Persada. 2018)

Karlina, Teknik Penyusunan Skala Likert, (Jakarta: Fatwa Publishing, 2013)

Mardani, Aspek Hukum Lembaga Keuangan Syariah di Indonesia, (Jakarta: Kharisma Putra Utama, 2015)

Muhammad, Suwarsono. "Manajemen Strategi Konsep dan Alat Analisis", (Yogyakarta: Unit Penerbit dan Percetakan Sekolah Tinggi Ilmu Manajemen YKPN. 2013)

M. Syafi'ie El-Bantanie, Zakat Infak dan Sedekah, (Bandung: Salamadani Pustaka Semesta, 2009)

Rohmat Agung Setiawan. Strategi Fundraising dalam Optimalisasi Penerimaan dan Pengelolaan Dana Zakat di Lembaga Amil Zakat OPSEZI Kota Jambi Tahun 2011-2015 (Jambi: Skripsi FEBI UIN STS Jambi, 2016)

Rozalinda. Ekonomi Islam Teori dan Aplikasinya pada Aktivitas Ekonomi, (Jakarta: Rajawali Pers. 2014).

Sayuti Una, Pedoman penulisan Skiripsi, (Jambi: Fakultas Syariah IAIN STS Jambi dan Syariah Press, 2012).

Sugioyo, Metode Penelitian Kuantitatif, Kualitatif, dan R\&D, (Bandung: ALFABETA. 2016) 